\title{
Aversive and aggression-promoting properties of urine from dominant and subordinate male mice
}

\author{
R. B. JONES and N.W. NOWELL* \\ Department of Zoology. The Unilersity. Hull. Yorkshire. England
}

\begin{abstract}
The urine of individual dominant and subordinate male mice was tested for aversive and aggression-promoting properties using open-field and aggression tests. The results indicate the presence of (1) an aversive factor in male mouse urine which discourages investigation of an area marked with such urine and (2) an aggression-promoting factor. Dominant male urine proved far more effective in both respects than subordinate urine. the latter having similar effects to water. The results are discussed in terms of androgen output and possible territorial functions.
\end{abstract}

The important role that olfaction plays in the regulation of social behavior in the mouse has been well documented (Mainardi, Marsan, \& Pasquali. 1965: Kalkowski, 1967; Ropartz, 1968). Urine provides a particularly efficacious odor source and tends to elicit, from conspecifics. social responses in accordance with the urine type (Mackintosh \& Grant, 1966: Mugford \& Nowell, 1970b).

Experiments performed in this laboratory (unpublished) clearly demonstrate the presence of an androgen-dependent aversive pheromone in male mouse urine which discourages prolonged investigation of an area marked with such urine. Krames, Carr. and Bergman (1969) have shown that male rats prefer to investigate the odor of submissive males rather than that of dominant males. We wanted to know whether the urine of a dominant male mouse would prove more aversive to another male than that of a subordinate. Thus, the main object of Experiment I was to determine whether a male mouse, when placed in a small open field. half of which had been treated by either dominant male urine. subordinate male urine, or water, would spend more time in one half than in the other half.

Male mouse urine also contains a pheromone that increases aggression in other male mice (Mackintosh \& Grant, 1966: Archer. 1968). Mugford and Nowell (1970a) have shown that this aggression-promoting pheromone is androgen dependent and that less is produced in nonaggressive than in aggressive males. However, this study used pooled urine samples. whereas in Experiment II we wanted to measure the aggression-promoting properties of the urine of individual dominant and subordinate males. It was considered that there might be a relationship between the aversive and the aggression-promoting properties of the different urines tested.

*R. B. Jones wishes to thank the Medical Research Council for financial support. We are also grateful to R. A. Dilks and F. Gillyon for their technical assistance.

\section{METHODS}

Animals

Albino mice of the Tuck T. T. strain, bred and maintained by the Liniversity of Hull Zoology Department, were used. The 24 urine donors, 12 dominant and 12 subordinate. were approximately 6-months-old exmated males that had been isolated for 2 months. The $24 \mathrm{Ss}$ used for the aversion test (Experiment I) were 5-month-old males. group housed in cages of six since weaning. The dominant male of each cage of Ss was not tested in an attempt to eliminate an! dominance/subordination variable. The $24 \mathrm{Ss}$ used in the aggression tests (Experiment II) were 6-month-old trained fighters that had been isolated for 2 months. Twenty-four nonaggressive castrate males were treated with the test urine and used as standard opponents to the fighters. Such practice has proved useful in previous experiments performed in this laboratory (Mugford \& Nowell, 1970a, 1972).

\section{Method of Urine Collection}

Approximately 3 days before the experiments, the 24 previously isolated male donors were randomly paired for $1 \mathrm{~h}$. during which time a dominant/subordinate relationship was clearly established. A wire-mesh divider was then put into each sage. This divider was removed 2 day's later. and the mice were allowed to fight for a short period. In each case the dominant/subordinate relationship had been maintained. in that the subordinate mouse immediately assumed submissive postures (Grant \& Mackintosh. 1963). Each pair was then placed into the urine collection apparatus described below. the dominant being put into one "compartment" and the subordinate into the other The mice were allowed $24 \mathrm{~h}$ acclimatization before collection began. Lrine was collected over $16 \mathrm{~h}$ daily. from 18:00 h to 10:00 $\mathrm{h}$ the following morning. This was followed by feeding for the remaining $8 \mathrm{~h}$. Water was supplied continuously. The dominant/subordinate relationship was maintained by fighting the mice at regular intervals during their period in the apparatus.

The authors felt that the urine should be collected from mice subjected to a minimum of stress. since mice that are stressed. for esample. by blowing air upon them or by electroshock excrete urine. the smell of which causes avoidance by other mice or otherwise interferes with conditioning experiments Mü̈ller-Velten. 1966: Sprott. 1969: Carr. Martorano. \& Krams: 1970). For this reason. a specially designed apparatus that reduces handling and permits free movamint was used to collast the urine.

The apparatus concists essentially of a Gridweld animal age 
Table I

Means and Standard Errors of the Time Spent in 1 ach Halt of the Open Field and of the Number of "Boser" 1 ntered

\begin{tabular}{|c|c|c|c|}
\hline $\begin{array}{c}\text { Test } \\
\text { Categories } \\
\end{array}$ & $\begin{array}{l}\text { Tume Spent un } \\
\text { Cle,sn H.tlt }\end{array}$ & $\begin{array}{l}\text { Time Spent in } \\
\text { Treded H.llt }\end{array}$ & 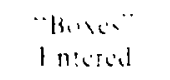 \\
\hline $\begin{array}{l}\text { Dominant } \\
\text { Irale Line }\end{array}$ & $2114.5-5418 \div$ & $411^{-} \cdot 5411$ & $0.4 \cdot+14$ \\
\hline $\begin{array}{l}\text { Subordinate } \\
\text { Ifale linine }\end{array}$ & $15-\ldots z-2.5 \times$ & $142.7 \cdot 235$ & 91.t: $=4=$ \\
\hline Matet & $151.9 \cdot 2.4-$ & $\begin{array}{r}145.21 \cdot 2.4- \\
11.11\end{array}$ & $411.4=4.25$ \\
\hline
\end{tabular}

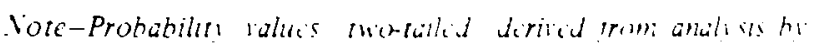
the Mam-lihime's $L \cdot t$ 'st

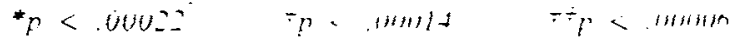

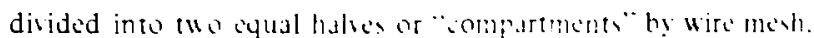
two rectangular high-impset polsutyrene tunns, with a bore

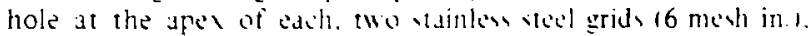
and two length of poly cthylene iubing. I th funnel accurately fits and drain iti respestive halt of the cage. The sted grids. placed inside the funnel. prevent the parage of fecal pellets hut allow the passage of urine. which rum down the polyethylene tubing and into collcotion wesse. This apparatus is a modjfication of another described chewhere lJones. Dilks a lowell. in prexil.

The urine wa then tested for it aberive (E vperiment $l$ ) and its aggresion-promoting propertie (I yperiment Il).

\section{EXPERIMENT I}

The aversive efficaly of the urine was tested by measuring the investigatory behavior of the $24 \mathrm{Ss}$ in an open field. which consisted of a black metal tank measuring $16 \times 11 \times 9 \mathrm{in}$. high and containing a sheet of unprinted newspaper as substrate. The paper was divided into two equal halves by a faint pencil line. and each half was then divided into quarters or "boxes" by the same method. Each $\mathrm{S}$ was put into a small Perspex cage that was then placed on the midline in the test tank. Trials were not started until the $S$ emerged from the small cage. which was then removed and washed in preparation for the next trial.

Three test situations were used in this investigation: in all cases. One half of the paper was spotted with nine equidistantly spaced drops of one of the following liquids: water. dominant male urine, subordinate male urine. The water category functioned as a control. Twenty-four trials of 5 -min duration were performed in each of the three situations. Trials were rotated between the various categories in an attempt to eliminate habituation to any particular test situation. Preference for either half was measured by the accumulated time spent in each half during the trial, and an approximate measure of activity was obtained by the number of boxes entered. The whole body of the mouse. apart from the tail. was required to cross the line in order to constitute an entry. The tank was cleaned with a mild solution of disinfectant after each trial, and the sheet of paper was changed.
Results

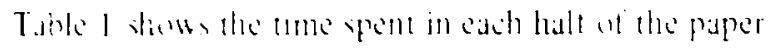
and the number of boves entered. Dry hall and wet hali are the inderis used in the water test ajegery. In this atcerory. the ume spent in the two halves did not differ ignificuml! $(p<.24)$. Which suggests that humidity

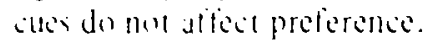

When the urine of dominant males was used. Ss showed a marked proference for the clean untreated hali "I the paper $(p<00006$ ). Ss also exhibited a significant preterence lat the dean halt when subordinate male urine was used $(p<.0002)$. hut this was significantly less $(p<00000)$ than the preference shown when the urine of duminant males was used. In addition, the time spent in the clean half when subordinate male urine was used did not differ significantly $(p<.074)$ from that spent in the dry half of the water category.

Table 1 also show's that the number of boxes entered by the Ss was significantly lower $(p<.00014)$ when the paper was trated with dominant male urine rather than subordinate male urine or water. The two latter ategories showed no significant difference $(p<.26)$ in this respect.

\section{EXPERIMENT II}

Aggression resting took place in an $11 \times 8 \times 4$ in. Makrolon cage containing clean sawdust that was changed for each trial. The "fighter" mice had previous experience of victory over castrates and had shown consistently high levels of aggressiveness during the training bouts. Individual urine samples. taken fresh from the donor mice. were painted onto the coats of the castrate opponent mice immediately before introducing them into the test cage. Water acted as a control. The fighter and the castrate opponent were separated in the test cage by a wire-mesh divider that was removed $1 \mathrm{~min}$ after their introduction. The aggressiveness of the fighter in a 4-min observation period was assessed by: (1) the latency up to the first bite of the castrate. (2) the total number of bites delivered, and (3) the accumulated time spent attacking the opponent mouse; this included biting. chasing. and wrestling. Twenty-four such trials were performed under each test situation.

\section{Results}

The results in Table 2 show that the urine of dominant males induces a high level of aggression on all measures. when painted onto castrate opponents. whereas the urine of subordinate males is not significantly different from water in promoting aggression.

\section{DISCUSSION}

The results of Experiment I support those of previous 
work carried out in this laboratory (unpublished) that demonstrated the presence of a factor in male mouse urine which discourages prolonged investigation. at least by subordinate males. of an area marked with such urine. Aversive stimuli suppress exploratory behavior (Baron, 1964: Kumar. 1970), thus, this urinary factor would seem to function as an aversive stimulus.

When the open field was treated with dominant male urine, Ss showed a distinct preference for the clean half. whereas subordinate male urine was far less effective in inducing this phenomenon. It seems reasonable to assume that higher levels of this "aversive" pheromone are being released by the dominant males than by the subordinates. A similar effect is apparent in the aggression tests where dominant male urine. painted onto castrate opponents, promotes high levels of aggression, but the urine of subordinate males is no more effective than water in this respect.

It has often been suggested (Thiessen. 1963: Denenberg, 1969) that reduced activity indicates greater emotionality. and it would seem, therefore, that the aversive pheromone of dominant males does induce greater emotionality. as indicated by the reduction in activity scores provided by treatment of the open field with dominant male urine.

Because both the pheromones described here are androgen dependent, the low effectiveness of subordinate male urine compared with dominant male urine may be due to differences in androgen output.

Evidence suggests that subjection to defeat causes marked activation of the pituitary-adrenocortical axis in mice (Bronson \& Eleftheriou. 1964. 1965). It is also true that an increase in social stress. as indicated by an elevation in adrenal weight and corticosterone output. is accompanied by a decrease in ventral prostate weight (Brain \& Nowell. 1970). Since the ventral prostate is sensitive to endogenous androgens. this is strong evidence that increased stress results in a decreased androgen output. In the present experiment. the subordinate animal was subjected to a high level of social stress due to the aggressive behavior of its dominant partner. Thus. the low levels of the androgen-dependent pheromones may be a result of the considerable stress suffered by the subordinate.

Our results conflict with those of Carr et al (1970). who found that the odor of shocked (stressed) mice caused avoidance by other mice. However. this conflict may be due to the different methods used or. possibly as a consequence of this. to the release of qualitatively different odors.

The present results also disagree with those of Whittier and McReynolds (1965) and those of Rowe (1970). who found an attraction to conspecific male odor. but this again may be due to the different methods used. Neither of these studies investigated the effect of urine per se but rather used the composite body odor of the donor animal. Rowe's preference tests were conducted in the home cage of each S. and. therefore.
Table 2

Means and Standard Errors of the Aggression Scores of Trained Fighter Mice Under Different Test Situations

\begin{tabular}{lccc}
\hline $\begin{array}{l}\text { Aggression } \\
\text { Scores }\end{array}$ & $\begin{array}{c}\text { Dominant } \\
\text { Nale Lirine }\end{array}$ & $\begin{array}{l}\text { Subordinate } \\
\text { Male Lrine }\end{array}$ & Water \\
\hline $\begin{array}{l}\text { Latency to } \\
\text { First Bite }\end{array}$ & $15.95 \pm 3.90^{*}$ & $76.25 \pm 19.29$ & $76.42=15.92$ \\
$\begin{array}{l}\text { Number } \\
\text { of Bites }\end{array}$ & $41.16 \pm 3.08 \div$ & $16.83 \pm 1.77$ & $15.04=1.71$ \\
$\begin{array}{l}\text { Accumulated } \\
\text { Attacking Time }\end{array}$ & $45.25 \pm 3.33 \div$ & $21.13 \pm 2.43$ & $18.79 \pm 1.99$ \\
\hline
\end{tabular}

Sote-Probability values (twatailed) derived from analysis by. the Mann-Whitney $l$-test.

$$
{ }^{*} p<.0018 \quad \stackrel{+}{ } \quad<.00006
$$

any positive response by the resident toward foreign mouse odor can be related to latent territorial aggression.

The present results could bear relevance to the concepts of territoriality. It is generally recognized that territorial behavior is a well-developed part of the social repertoire of .Hus musculus (Crowcroft \& Rowe. 1963: Anderson \& Hill. 1965). The concept of territory includes marking as well as defense (Hediger, 1950. 1955), and urine would seem a particularly suitable marking agent. It is, in fact, used for such a purpose by a wide variety of animals (Hediger, 1950). If. under natural conditions. male conspecifics were deterred from investigation of an area marked with the urine of another male mouse. this could aid considerably in maintaining the integrity of that area. Only the most aggressive dominant males are likely' to hold territories. and. therefore, it seems fitting that their urine should possess stronger aversive properties than that of low-ranking nonterritory-owning males.

It is possible that the urine of a dominant male holds more "threat" value than that of a subordinate to a strange conspecific and. depending upon the stranger's previous experience and the environmental conditions. this threat may result in avoidance or at tack.

It would seem beneficial to a subordinate male not to produce much aggression-promoting pheromone. whereas the promotion of aggression between dominant males may insure that high ranks and/or territories are held only by the fittest candidates.

It is not yet clear whether the aversive and the aggression-promoting factors are two distinct pheromones or whether they are the same pheromone exerting different effects under different conditions. Further investigation may clarify this situation.

\section{REFERENCES}

Anderion. P. K.. \& Hill. J. L. Wus musculus: Fuperimental industion of territory formation. Science. 1965. 148 1753.1755 .

Archer. I. 1. The effect of strange male odor on aggresile hehuior in male mica. Journal of Mummalog!. 1968. 49. $572 \div ? 5$ 


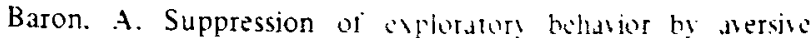
stimulation. Joumal of Cimparatice \& Physiological Psychology. 1964. 57. 299.301

Brain. P. F.. \& Nowell. N. W. The etfects of differential grouping on endocrine function of muture mula alhino miec. Phy siology $\&$ Behavior. 1970. 5.907-910.

Bronson. F. H.. \& Elefthirou. B. 1. Chronic physiological effects of fighting in mice. Cieneral \& Comparative Endocrinology 1964. 4. 9-14.

Bronson. F. H.. \& Eleftheriou. B. L. Relative affects of fighting on bound and unbound corticusterone in mice. Proceedings of the Society for Experimental Biology \& Medicine. 1965, 118. 146-149.

Car. W. J.. Martorano. R. D.. \& Krames. L. Responses of mice to odors associated with stress. Joumal of Comparative \& Physiological Psychology. 1970. 71. 223-228.

Crowcroft. P.. \& Rowe. 1. Social organication and territorial behaviour in the wild house mousc. Procedings of the Zoological Society of London. 1963. 140. 517-531.

Denenberg. V. H. Open-field behavior in the rat: What does it mean? Annals of the lew lork tiademy of Sicnce. 1969. 159. 852-859.

Grant. E. C.. \& Mackintosh. J. H. I comparison of the social postures of some common laboratory rodents. Animal Behavior, 1963. 21. 246-259.

Hediger. H. Wild animals in captivit. London: Butterworth. 1950.

Hediger, H. Studies of the psychology and behavior of captive animals in zoos and circuses. New York: Criterion Books. 1955.

Jones. R. B.. Dilks, R. A.. \& Nowell. N. W. A method for the collection of individual mouse urine. Physiology \& Behavior, 1973.10. 163-164.

Kalkouski. W. Olfactory bases of social orientation in the white mouse. Folia Biologica. 1967. 15.69-87.

Krames. L.. Cars. W. J.. \& Bergman. B. A pheromone associated with social dominance among male rats. Psychonomic Science, 1969, 16, 11-12.

Kumar. R. Effects of fear on exploratory behavior in rats. Quarterly Journal of Experimental Psychology, 1970, 22, 205-214.
Mackintosh. J. H. \& Grant. E. C. The effect of olfactory stimuli on the agonistic behavior of laboratory mice. Zeitschrift für Tierpsychologic, 1966. 23. 584-587.

Mainardi. D.. Marsan. M.. \& Pasquali. A. Causation of sexual preferences in the house mouse: The behavior of mice reared by parents whose odor was artificially altered. Attj della Società I taliana di Scienze Naturali e del Museo Civico di Storia Naturali di Milano. 1965, 104. 325-338.

Nugford. R. A..\& Nowell. N. II. Pheromones and their effect on aggression in mice. Nature, 1970a. 226, 967-968.

Mugford. R. A.. \& Nowell. N. W. The aggression of male mice against androgenized females. Psychonomic Science. $1970 \mathrm{~b}$. 20, 191-192.

Mugford. R. A.. \& Nowell. N. W. The dose-response to testosterone propionate of preputial glands. pheromones. and aggression in mice. Hormones \& Behavior. 1972. 3. 39-46.

Müller-Velten. H. Über den angstgeruch bei der Hausmaus (.ITLS musculus L.). Zeitschrift für Vergleichende Physiologie, 1966. $52,401-429$.

Ropartz. P. The relation between olfactory stimulation and aggressive behavior in mice. Animal Behavior. 1968. 16. 97-100.

Rowe. F. P. The response of wild house mice (Nus musculus) to live traps marked by their own and by a foreign mouse odour. Journal of Zoology' (London), 1970. 162. 517-520.

Sprott, R. L. "Fear communication" via odor in inbred mice. Psychological Reports, 1969. 25. 263-268.

Thiessen, D. D. Varying sensitivity of C57Bl/Crgl mice to grouping. Science. 1963, 141.825-828.

Whittier. J. L.. \& McReynolds, P. Persisting odors as a biasing factor in open field research with mice. Canadian Journal of Psychology, 1965. 19. 224-230.

(Received for publication February 16. 1973; revision accepted April 10. 1973.) 